\title{
Factors Influencing Failure of Reading
}

\author{
Anis Mawati \\ MTS N Ngemplak \\ Jl. Waduk Cengklik, Ngesrep, Ngemplak \\ anismawati42@yahoo.com
}

\section{Abstract}

The objective of this research are: to find out the forms of failure of reading in English texts in English learning, to find out the factors influencing the failure of reading English texts in English learning, to find out how does the failure of reading English texts influence English learning process, to find out the ways of teacher to overcame failure of reading English texts in English learning among students. The result of the research are: The less time allocation of teaching and learning, The lack of students' self-confident in English learning because of the lack of vocabulary. The dominant factor influencing the failures of reading English texts in English learning are: the students' weak understanding of grammar and vocabulary. The teacher's effort to overcame reading failure are: asking the students to make exercise of English learning by working in groups, Asking the students to read English text and then asking the other students to scrutinize it.

Keywords: Failure of reading, English text, English learning, Teacher's effort.

\section{Abstrak}

Tujuan dari penelitian ini adalah: mengetahui bentuk kegagalan membaca teks bahasa Inggris dalam pembelajaran bahasa Inggris, mengetahui faktor yang mempengaruhi kegagalan membaca teks bahasa Inggris dalam pembelajaran bahasa Inggris, mengetahui seberapa jauh kegagalan membaca teks bahasa Inggris mempengaruhi proses pembelajaran bahasa Inggris, mengetahui cara-cara guru untuk mengatasi kegagalan siswa dalam membaca teks bahasa Inggris dalam pembelajaran bahasa Inggris. Hasil penelitian ini adalah: sedikitnya alokasi waktu pembelajaran, Kurangnya percaya diri pada diri siswa dalam belajar bahasa Inggris 


\section{Factors Influencing Failure of Reading}

karena kurangnya kosa kata. Faktor dominan yang mempengaruhi kegagalan membaca teks bahasa Inggris dalam pembelajaran bahasa Inggris adalah: lemahnya pemahaman siswa dalam hal tata bahasa dan kosa kata. Upaya guru untuk mengatasi kegagalan membaca adalah: meminta siswa untuk membuat latihan pembelajaran bahasa Inggris dengan bekerja dalam kelompok, Meminta siswa untuk membaca teks bahasa Inggris dan kemudian meminta siswa lain untuk mengoreksinya.

Kata Kunci: Kegagalan membaca, Teks berbahasa Inggris, Pembelajaran Bahasa Inggris, Upaya guru.

\section{Introduction}

In this globalization era, English is very important to study, since it is an international language. Before discussing further, the writer will describe about the language. English is an international language used in countries through out the world including Indonesia. Here it is not only considered as the first foreign language, but it is taught as compulsory subject from the junior high school up to senior high school. Although it has been taught for a long time, the result of teaching English is still considered unsatisfactory.

Language has complex role in communication. Therefore, they do not need just one language, but also two or more. Related to with the statement, language is divided into three part. First, language is called "Mother Tongue" which is used to communicate daily in the family and surroundings. The second language is the national language. This language is determined by government, for example Indonesia language for Indonesian people. The language is a language which is used at school and official, it also taught to the student. Then the third is language is foreign language taught at school and formal and information institution. The foreign language is like English.

English will not be difficult for tudents who have enough time to 
study. It is because they have found suitable ways of doing it. Many Indonesian people nowadays keep trying to improve their English by taking either formal or non formal courses. English is introduced in to the curriculum and considered as the first foreign language to be taught at school in Indonesian. It has been going on up to now the understand skill, the goal teaching English is to develop student English communication, which consist of reading, listening, writing and speaking. But in the language learning, we often find difficulties to understand it. Same people with severe physical problems have no physical impediment, good home, a nice neighborhood and good teacher, do not learn as well as might be excepted them.

Questions that way some people do not learn to read at all, or why they read as well as might be expected, or how we can determine what causes may be most influence in producing failure in reading, may be answered by investigating physical, educational, and psychological factors, three broad areas of causation we can included almost all of the known reasons for reading failure, certainly enough to be practically useful in classroom. In the English learning we often difficult to understand it. In this research we will explain some of the factors reading failure in the English language learning that make we difficult to learn it. Beside that reading is the thing important in the English language learning, because with the reading the learner will get information.

Based on the problem statement above, the objective of the study are as follows: (1) To find out the forms of failure of reading in the English texts in English learning. (2) To find out the factors influencing the failure of reading English texts in English learning. (3)To find out the how far failure of reading English texts influence English learning process. (4) To find out the teacher ways to overcame failure of reading English texts in 


\section{Factors Influencing Failure of Reading}

English learning among students.

\section{Theoretical Framework}

The American Heritage Dictionary of the English language gives the meaning of cognition as "The mental process by which knowledge is acquired. There are several basic characteristic of cognition (Fauzi, 2004:24). One of them is cognition process. This process is mental. This process is purposive. By implication, this process is internal. By implication this process is ultimately under the control of the learner, even if one is coerced in to learning by external pressure. "Thus, the term cognitive process refers to the individual internal mental operation. It my involve conscious attention to some point the teaching is making, conscious reorganization of material to understand better the concept being learned information.

One of the leading cognitive psychologists is David Ausubel. In this book, the states that there are two types of learning: root learning and meaningful learning. The crucial factor determining whether learning is rote or meaningful is the manner in which the material is learned arbitrary and verbatim.

The key concept in Ausubel cognitive theories of learning is that learning must be meaningful. The learner must understand what is to be learned. The implication is that learning must involve active mental process in order to be meaningful learning can student acquire significant amount of knowledge (Ibid:25).

Although specifics theories of the nature of language may provide the basis for a particular teaching method, other methods derive primarily from a theory of language learning. A learning theory underlying an approach or methods responds to two questions. 
a. What are the psycholinguistic and cognitive processes involved in language learning?

b. What are the conditions that need to be met in order for this learning process to be activated?

Learning theories associated with a method at the level of approach may emphasize the nature of the human and phsycal context in which language learning takes place (Richards and Rodgers: 16).

Stephen D. Krashen's Monitor Models of Second Language Development is an example of learning theory on which a method (the natural approach) has been built.

Monitor theory addresses both the process; Krashen distinguishes between acquisition and learning. Acquisition refers to the natural assimilation of language rules through using language for communication. Learning refers to the formal study of language rules and is a conscious process.

In this classic work on the conditions of learning, Robert Gagne say that ably demonstrated the importance of identifying a number of different types of learning which all humans use. Types of learning vary according complex task such as language learning involves every one of Gane's types of learning-from simple signal learning to problem solving (Brown, 1980:80).

Gagne's identifies eight types of learning: (c) Signal learning, (d) Stimulus-response learning, (e) Chaining, (f) Verbal association, (g) Multiple discrimination, (h) Concept learning, (i) Principle learning, (j) Problem solving.

Since all eight types of learning are relevant to second language learning, the implication is that certain "lower"-level aspects of second language 


\section{Factors Influencing Failure of Reading}

learning may be more adequately treated by Behavioristic approaches and methods, while certain "higher"-order types of learning are more effectively taught by methods derived from a cognitive approach term by means of the types of learning.

In language learning we can distinguish two basic categories of strategies: learning strategies and communication strategies. A learning strategy is a method of perceiving and storing particular items for later recall. A communication strategy is a method of achieving communication, of encoding or expressing meaning in language. The two types of strategies are quite different in their manifestation, though there is obviously is strong relationship between them (Ibid: 83).

Most definitions of reading given in professional text books are of this second type. De Boer and Dallman consider that reading "Involves the comprehension and interpretation of ideas symbolized by the written or printed page". In later book the authors note that their emphasis is on "Reading as a process involving meaningful reaction to printed symbols (Dechant:4). "Bond and Tinker point out that" reading involves the recognition of printed or written symbols which serve as stimuli for the recall of meaning built up through the reader's past experience. "Harris and Sipay define reading as "the meaningful interpretation of written or printed verbal symbols". Gibson says that reading is receiving communication: it is making discriminative responses to graphic symbols: it is decoding graphic symbols to speech: and it is getting meaning from the printed page".

These definitions of reading have certain elements in common: particular, they all note that reading is an interpretation of graphics symbol. Reading is thus perceived as a twofold process:

1. Identification of the symbols 
2. Association of appropriate meaning with them.

Reading requires identifications and comprehension. Reading always involves an interaction between the writer and reader. It is the culminating act of the communication process, initiated by the thoughts of the writer and expressed thought the symbols on the page.

Thorndike maintained years ago that the reading of a paragraph involve the same sort organization and analysis as does thinking. It includes learning, reflection, judgment, analysis, synthesis, problem, solving behavior, selection, organization, comparison of date, determination of relationships, and critical evaluation of what is being read. Examine now more closely two important aspect of the reading process:

1. The language or sign system of reading which the reader must identify and recognize and in which the message are formulated or encoded.

2. The decoding or comprehension process in which the reader must engage.

Reading failure is something that make impede the process of language learning activity which causes of same problems that have negative influence toward a learner in English learning.

The other factors influencing failure of reading English text is:

(a) Physical factors, Includes in this group are all auditory and visual problems: physiological factors in the organism, especially the brain and nervous system, which are defective or dysfunctions perceptual anomalies, retardation, Celebral palsy, aphasia, and alexia are all physical problems which have been studied for their relationship to reading and other language disabilities. 


\section{Factors Influencing Failure of Reading}

(b) Educational Factor, In this group is included what schools, teachers, administrator, circular, parent, community and society do for us in the name of education. As john Half suggest, make children stupid in school? Do the complaints of disciplinary problems and delinquents and drop-outs mean anything when they say that the school, the teacher, did not care about them or what they were doing? Obviously, all of the factors make same difference (Howards, 1980:160). We simply cannot believe that any one is all right or all wrong in these circumstances.

(c) Psychological factor, In this group all else merges. Our cognitive are permitted with effect, and our effective responses are somewhat altered by our cognition. Emotion such as pride, fear, anxerty, trust, love and note are powerful under currents pulling is unexpectedly. It is difficult to identify the exact emotion which may be affecting us at a given time, and it is even more difficult to say just how much anxiety or fear, for example may be distracting us from our tasks. We know that emotion do directly affect all learning and behavior, and their effects, but feelings evade measurement and controlled study.

Complete reading is said to in value four steps: recognition, understanding, reaction and integration. Ultimately, it is hoped that the reading a child does will influence and direct same future activity children. Integrate what they are reading, they are studying. This may be the ultimate in comprehension. Gray point out that integration is "The heart of the learning act in reading. The reading is complete only when that which is read becomes assimilated".

Integrative reading is commonly identified with study-related reading. Herber defined study skills in reading as work skills that produce useful knowledge for a learner; they are reading skill especially adapted to 
execute particular tasks. They help the students to develop ideas, to remember ideas and to use ideas.

\section{Research Methodology}

A. Research Methodology: (1) Type of Research. Research is about inquiry, and its product is knowledge. In this research, the writer uses qualitative and quantitative research. But qualitative research is dominant in this research. Qualitative research is a type of research which does not include any calculation or enumerating (Brannen,1997:11). If there is any calculation in this research, they just to answer the third problem. More of them calculation are as data. In this research descriptive is dominant. To answer the first, second and fourth problem, the writer uses description and explanation. This graduating paper is discussing about problem occurs in the English learning. That is why the writer believes that qualitative research is more appropriate to this research. (2) Population, The population of research is all the members of the research subject. They are the students of the second year of MTsN I Gondangrejo Karanganyar Surakarta in academic year 2005 / 2006. The total of students of six classes in the population are 264 students, each consist 44 students that year in MTsN Gondangrejo Karanganyar. (3) Sample, A sample is part of population that represent the whole population (Nadzir: 325). In this the writer take class II MTsN Gondangrejo Karanganyar in the year 2005 / 2006 as sample. A research may take one class of the population, it equal to 44 students.

B. Method of Data Collecting: (1) Questionnaire Method, Questionnaire is written question used to get information from respondent. It is report of their private of their private of other things they know (Kartono,1990:217). The study uses the closed questionnaire and it can be 


\section{Factors Influencing Failure of Reading}

used get the data about how far failure of reading English text, forms reading failure and the influence in English learning. (2) Interview is "Percakapan dengan bertatap muka dengan tujuan memperoleh informasi actual, untuk menaksir dan menilai kepribadian individu, atau untuk tujuan-tujuan konseling / penyuluhan, atau tujuan suatu masalah tertentu" (Ibid:187). Or interview is the dialogue is face to face with purpose or the problem purpose. In the other ward interview is dialogue between interviewer and interview to get information by asking English teacher about his methods teaching English texts among his students with direct.

Data Analysis, The writer analyzed the data using following steps:

1. Identifications Step, The writer identified the result of the students' test in reading English text and comprehension. With way correction of the result that it was given to the students.

2. Analysis Step, The data has been identified. The writer analyzes the students answer in test.

3. Finding the Result, After it is classified into table of the result, so the writer can count the result of students' text with formula as follow:

$$
\mathrm{P}=\frac{F}{N} \times 100 \%
$$

\section{Explanation:}

F : Frequency is looked for the percentage

$\mathrm{N} \quad$ : Number of cases (number of frequency of number of individual)

P : Percentage

4. Analyzing the result of the students after it counted.

5. Find out the forms, factors and how far the influence of reading failure in English learning. 
6. Analyzing the result of the interview of English teacher about the ways overcame reading failure among his students.

7. All of conclusions of the test an interview result are analyzed again using deductive and inductive to make sure and valid.

8. The data are interpreted.

\section{Discussion}

The student's failure in reading English texts

Table VII

The student's failure in reading

\begin{tabular}{|c|c|c|}
\hline $\begin{array}{l}\text { Number of } \\
\text { question }\end{array}$ & $\begin{array}{c}\text { Percentage of correct } \\
\text { answer }\end{array}$ & $\begin{array}{c}\text { Percentage of false } \\
\text { answer }\end{array}$ \\
\hline 1 & $100 \%$ & $0 \%$ \\
\hline 2 & $81 \%$ & $19 \%$ \\
\hline 3 & $84 \%$ & $16 \%$ \\
\hline 4 & $72 \%$ & $28 \%$ \\
\hline 5 & $97 \%$ & $3 \%$ \\
\hline 6 & $72 \%$ & $28 \%$ \\
\hline 7 & $75 \%$ & $25 \%$ \\
\hline 8 & $52 \%$ & $48 \%$ \\
\hline 9 & $90 \%$ & $10 \%$ \\
\hline 10 & $61 \%$ & $39 \%$ \\
\hline 11 & $75 \%$ & $25 \%$ \\
\hline 12 & $50 \%$ & $50 \%$ \\
\hline 13 & $59 \%$ & $41 \%$ \\
\hline 14 & $68 \%$ & $32 \%$ \\
\hline 15 & $50 \%$ & $50 \%$ \\
\hline 16 & $25 \%$ & $75 \%$ \\
\hline 17 & $93 \%$ & $7 \%$ \\
\hline 18 & $32 \%$ & $68 \%$ \\
\hline 19 & $18 \%$ & $82 \%$ \\
\hline 20 & $59 \%$ & $41 \%$ \\
\hline
\end{tabular}




\section{Factors Influencing Failure of Reading}

This is the analysis of the answer from 20 items in the question.

From the percentage of students answer correct and false in the table above, the writer can analyzes the first question until the last question. (a) In the question number one, all of the students answer correctly. Because in this question is a group of easy question. It is just to know carefulness of students in the reading of text. (b) In the question number two 19\% student's answer false. Because every student, they are have different knowledge, and in question number three, four and five. Most of the students less careful in reading text, this happened because some of the students misunderstanding with the vocabulary in the text about the meaning names days. (c) In the question number six $28 \%$ students give a false answer it happens because many students didn't know the meaning or the use of word "always" and "every morning". It is make students failure in the answer of question. (d) In the question number seven $25 \%$ students give a false answer it happens because, students defrauded with the answer, the students forget with the conjunction "then" in the answer, the students forget with the conjunction "then" in the answer. (e) In the question number eight $48 \%$ students give a false answer it happens because, the student less of careful in the answer. The although the answer has available in the text, but students still defrauded with the other answer. (f) The question number nine, most of the student's answer are correct. It happens because the number in the first sentence and the last paragraph. So the students not difficulted to seek answer it. (g) From the question number ten $39 \%$ students give a false answer it happens, because in this question, the write use apostrophe in to make question. So this make student confused in the answer it. (h) In the question number eleven, they are many students give a false answer it happens, 25\% students answer false, this happen because students didn't know how to use subject as 
object or natural subject. (i) The question number twelve $50 \%$ students give a false answer it happens, this case like in the number thirteen, fourteen and fifteen. They are also use apostrophe. Most of them false answered while they found the questions the use apostrophe. It is caused by misunderstanding in grammar. (j) In the number sixteen only quarter percentage students that answer correctly. This happens because most of the students didn't know how to differences about using subject as object in the singular or plural. (k) In the question number seventeen almost are answer correct, this happens caused the students has understood in the reading text. (1) This question is different with number seventeen, the although in the question number eighteen has the some level of difficulty, but in this question $82 \%$ students give a false answer it happens. This happens because student's nervous and afraid if the time not suitable has decided. So, the concentration was disturbed. (m) The question number nineteen thus case like the previous question number, they fail in the use apostrophe. (n) In the last question $41 \%$ students give a false answer it happens, this happens because the students less of careful in the execution it. Because this is last question the students may be are also are weak. The analysis answer from four questions.

a. The form of reading failure in English learning and how far its influence.

The writer gives question to answer the problem. If we look at the result of the students test, we know that there are various answer. Many students who failed in reading English text. It is caused by less time allocation. Besides they also difficult in reading. They could not understand the meaning English text. Such errors interfere their comprehension as well as the ability to understand what they read. 


\section{Factors Influencing Failure of Reading}

Good reading is the readers must attend their pronunciation and grammar. Besides the most important, the reader must understand with what they read. By this way students what they read as good as that they read as good as that they want. For seventh students answer that the dominantly they are confident or not sure with their answer. Their reasons are they little vocabulary that they known.

The form of the fourth that failed in reading is misunderstanding in English text. From the forms of reading failure above the writer conclude that dominant factors reading failure in English texts are caused by less understanding students about grammar and vocabulary in the meaning English texts.

Beside the above forms, the writer also gave question about how far the failure of reading English texts influenced the process of English learning to students. And from 40 student's answers, they influence English learning process. So, we know the effect of its. And it is also any of the hazard of English learning that we should avoid with give students more examination, so that it will increase their ability to master new vocabulary.

b. Factors dominant of reading failures in English texts.

To answer this problem, the writer gave question about dominant factors of reading failure. There are 20 students whose answer are grammar and vocabulary. Their reasons are English learning is difficult to study. There are 13 students who answered that environment influence the learning. Their reasons are English is foreign language in Indonesia it is not our own language. In other hand we different methods to understand it. For 11 students whose answers are physical. Their reasons are that they have inadequacy of the brain. It is caused by inactivity of the brain to 
think. And it makes them often failure in reading. From the answers above, the writer conclude that the dominant factor of reading failure is mastery of grammar and vocabulary. It

c. The English teacher ways to overcame reading failure among his students.

To answer the problem about the ways to overcame reading failure in English learning, the writer interviewed English teacher. The teacher says that in some he overcame by careful process of education under a competent tutor. Beside that he also makes a group from students to examine English learning. For example to make students enjoy English learning a teacher uses games.

He also often ask students to read English text and ask the other student to scrutinize. And if there students didn't know in their group about what the teacher explain to them, the reader of the group must be responsible with give explain to friend his group to know. The teacher is sure, that the explain from friend themselves are, more affective them their teacher. And besides the teacher also gives priority to personal approach with his students.

But in out of the class, the control is family, environment and their attitude. Drilling and giving a good model is also his way to overcame reading failure. A good model is teacher with good example of student.

This study also can show to the reader that the most influence of reading failure, which often happens among students of the second year of MTsN 1 Gondangrejo Karanganyar Suarakarta in the academic 2005/2006, is difficult to understand the meaning of texts. And the dominant factor is misunderstanding about grammar and vocabulary in English learning. The way to overcame it is suitable with the case. 


\section{Factors Influencing Failure of Reading}

\section{Conclusion}

From the research, that researcher did in MTs I Gondangrejo Karanganyar Surakarta, the writer concludes as fallow.

1. The forms of failure of reading text in the English learning and now it's influence according to the statement's answer, the influence of the reading failure to English learning are: (a)The less time allocation, (b)The less of self confident in English learning because of minimum vocabulary, (c)Misunderstanding in the meaning of reading English texts

2. The dominant factor influencing the failures of reading English texts in English learning. The students answered that the dominant factor of reading failure are: (a) The understanding of grammar and vocabulary are weak. (b) Physical, for example sick, nervous, inactivity of brain and tired. (c) Environment of student. Because English is foreign language in Indonesia.

3. The teacher ways to overcame reading failure. From the result of interview with teacher use overcame reading failure, there are: (a) A careful process of education under of competent tutor. (b) Ask the students to exercise English learning white a make of the groups. (c) Ask the students to reading English text and ask the other students to scrutinize. (d) The teacher also gives priority to personal approach with students him. (e) The teacher makes of group and every group one leader. (f) Drilling and giving a good model to students.

\section{References}

Brown, Douglas. 1980. Principle of Language Learning And Teaching. New Jersey: Prentice Hall. Inc. 
Fauzy, Endang. 2004. Reading On AppliedLinguistics. Muhammadiyah University Press.

Ricard, Jack C. and Rojers Theodore S. Approach and Methods In Language Teaching. New York. Part Chester. Melbourne. Sidney: Cambridge University Press..

Dechan, Emeral V. Improving The Teaching of Readin. New Jersey: Prentice Hall. Inc.

Howard, Melvin.1980. Reading Diagnosis and Instruction. Reston. Virginia: A Prentice Hall. Company, Branen, Julia.1997. Memadu Metode Penelitian Kualitatif Kuantitatif. Jakarta: Pustaka Pelajar.

Nadzir, Muh. Ph. D. Metode Penelitian. Indonesia: Galia.

Kartono, Kartini.1990. Metodologi Riset Sosial. Bandung Maju. 
Factors Influencing Failure of Reading 